\title{
Bioactive 3D-Shaped Wound Dressings Synthesized from Bacterial Cellulose: Effect on Cell Adhesion of Polyvinyl Alcohol Integrated In Situ
}

\author{
Marlon Osorio, ${ }^{1}$ Jorge Velásquez-Cock, ${ }^{1}$ Luz Marina Restrepo, ${ }^{2}$ Robín Zuluaga, \\ Piedad Gañán, ${ }^{1}$ Orlando J. Rojas, ${ }^{4}$ Isabel Ortiz-Trujillo, ${ }^{5}$ and Cristina Castroo ${ }^{6}$ \\ ${ }^{1}$ Facultad de Ingeniería Química, Universidad Pontificia Bolivariana, Circular 1, No. 70-01, Medellín, Colombia \\ ${ }^{2}$ School of Health Sciences, Universidad de Antioquia, Calle 51D 62-29, Medellín, Colombia \\ ${ }^{3}$ Facultad de Ingeniería Agroindustrial, Universidad Pontificia Bolivariana, Circular 1, No. 70-01, Medellín, Colombia \\ ${ }^{4}$ Biobased Colloids and Materials Group (BiCMat), Department of Forest Product Technology, Aalto University, \\ School of Chemical Technology, Espoo, Finland \\ ${ }^{5}$ Facultad de Medicina, Universidad Pontificia Bolivariana, Calle 78B No. 72A-109, Medellín, Colombia \\ ${ }^{6}$ Facultad de Ingeniería Textil, Universidad Pontificia Bolivariana, Circular 1, No. 70-01, Medellín, Colombia
}

Correspondence should be addressed to Cristina Castro; cristina.castro@upb.edu.co

Received 5 March 2017; Accepted 1 August 2017; Published 18 September 2017

Academic Editor: Miriam H. Rafailovich

Copyright (C) 2017 Marlon Osorio et al. This is an open access article distributed under the Creative Commons Attribution License, which permits unrestricted use, distribution, and reproduction in any medium, provided the original work is properly cited.

We investigated wound dressing composites comprising fibrils of bacterial cellulose (BC) grown by fermentation in the presence of polyvinyl alcohol (PVA) followed by physical crosslinking. The reference biointerface, neat BC, favoured adhesion of fibroblasts owing to size exclusion effects. Furthermore, it resisted migration across the biomaterial. Such effects were minimized in the case of PVA/BC membranes. Therefore, the latter are suggested in cases where cell adhesion is to be avoided, for instance, in the design of interactive wound dressings with facile exudate control. The bioactivity and other properties of the membranes were related to their morphology and structure and considered those of collagen fibres. Bioactive materials were produced by simple 3D templating of $\mathrm{BC}$ during growth and proposed for burn and skin ulcer treatment.

\section{Introduction}

Skin ulcers and burns often result in extensive damage to the skin layers [1]. Significantly, burns induce anatomical, physiological, endocrinological, and immunological alterations [2]. In the United States alone, over two million burn injuries per year are brought to medical intervention. Most of these injuries are minor; however, approximately 20,000 patients sustain severe burns requiring admission to specialized units [3]. Most burn wounds are treated with sterile gauze, saline solution, and topical prophylaxis [4]. These treatments, however, are not fully effective for pain relief, hydration, and protection [5].

Modern wound dressings have been developed to facilitate functions at the wound area. These dressings are designed to prevent wound dehydration, promote healing [6], and reduce inflammatory and immune responses [7-12]. Modern wound dressings are classified as passive, interactive, or bioactive [6]. The sole role of passive dressings is protection while interactive dressings promote healing through a moist wound environment. Interactive dressings, however, not only maintain a moist environment but also interact with the components of the wound bed to further enhance healing $[6,13-15]$.

In wound dressing applications, there is a pressing need to develop biocompatible hydrogel biomaterials [16]. In this context, biocompatibility refers to the ability to perform with an appropriate host response in the given application [17-19]. For this purpose, hydrogels are ideally suited since they are able to absorb more than $70 \mathrm{wt} \%$ of their dry weight in water [8]. 
A number of studies have highlighted the use of polyvinyl alcohol (PVA), bacterial cellulose (BC), and their composites in biomedical applications, including scaffolds for tissue engineering, heart valves, articular cartilage, and artificial corneas [20-22]. In fact, PVA/BC nanocomposites have been tailored to suit the properties of skin, where BC and PVA mimic collagen and elastin for their roles in natural soft tissues [23]. In addition, PVA/BC biomaterials can be shaped into gloves, masks, and wearable webs due to the conformability of $\mathrm{BC}$ during its fermentation [1]. Shaped wound dressings provide a high degree of adherence to the tissues surrounding a lesion, preventing their detachment in areas that are subjected to movement (e.g., torso, hands, and face) [11].

Two primary approaches that are used toward PVA/BC nanocomposites include in situ and ex situ processing [23, 24]. In contrast to ex situ synthesis, nanocomposite biomaterials developed via in situ fermentation favour homogeneous material distribution, which promotes a number of synergistic properties [25]. In this case, crosslinking is required to limit the solubilization of the matrix. Recently, an in situ PVA/BC nanocomposite was developed via physical crosslinking (Castro et al.). This type of crosslinking avoids the use of toxic compounds, including chemical crosslinkers [26], some of which are known to be carcinogenic and neurotoxic [27]. The in situ PVA/BC nanocomposites developed so far present a highly porous, percolated morphology; their chemical, mechanical, and thermal properties make them appropriate as biomaterials [20, 26, 28-31]. Any biomedical application, however, demands in vitro assessments, which are available for BC biomaterials for wound dressings [3235]; however, to the best of our knowledge, no reports exist in this context for PVA/BC nanocomposites obtained via in situ fermentation.

Therefore, this study evaluates the morphological, mechanical, water adsorption, and in vitro performance (adherence and cell migration) of PVA, BC, and PVA/BC nanocomposites for wound dressing. Our efforts included the classification of the developed materials into currently accepted wound dressings. The results indicate possibilities for exudate management and the use of $\mathrm{BC}$ as bioactive wound dressing that facilitates skin cell regeneration.

\section{Materials and Methods}

2.1. Materials. Glucose (PubChem CID: 64689), yeast extract, peptone, disodium hydrogen phosphate (PubChem CID: 24203), citric acid (PubChem CID: 311), potassium hydroxide (PubChem CID 14797), silicon rubber, and PVA (molecular weight 89000-98000 and 99+\% hydrolysis, PubChem CID 11199) were all acquired from Sigma-Aldrich. Bacterial cellulose was produced by Komagataeibacter medellinensis $[36,37]$. Its elemental analysis included carbon $(44.2 \pm 1.6 \%)$, hydrogen $(6.3 \pm 0.25 \%)$, and nitrogen $(0.39$ $\pm 0.04 \%)$ [37]. The nitrogen content relates to the amino acids from the residual bacteria after purification. The BC crystallinity index is $\sim 0.65$, with a $\mathrm{I} \alpha / \mathrm{I} \beta$ ratio of $\sim 0.74$, indicating the enrichment of the I $\alpha$ polymorph [38]. Dulbecco's Modified Eagle Medium, foetal calf serum, and fibroblasts in primary culture were employed for cell culturing. All reagents were analytical grade. Fibroblasts were kindly donated by the Grupo de Ingeniería de Tejidos y Terapias Celulares, Universidad de Antioquia, Medellín, Colombia.

2.2. Bacterial Cellulose. In order to produce the BC biomaterial, $90 \mathrm{~mL}$ of Hestrin \& Schramm culture medium (HS) [39] was adjusted to $\mathrm{pH}=3.6$ with citric acid and then sterilized in autoclave at 15 psi for $15 \mathrm{~min}$. After reaching room temperature, the culture medium was inoculated with $10 \mathrm{v} / \mathrm{v} \%$ of Komagataeibacter medellinensis [37] and distributed in a six-well polystyrene plate. The fermentation was carried out for 7 days at $28^{\circ} \mathrm{C}$, after which the $\mathrm{BC}$ biomaterial was extracted and purified with $5 \mathrm{wt} \%$ of $\mathrm{KOH}$ solution at room temperature for $14 \mathrm{~h}$ followed by continuous rinsing with deionized water until $\mathrm{pH}=7.0$. The resultant material was sterilized in autoclave $\left(121^{\circ} \mathrm{C}\right.$ for 15 minutes) for later use.

2.3. PVA and PVA/BC Nanocomposites. The method to produce the PVA/BC nanocomposite included PVA (5 wt\% concentration) that was solubilized in aqueous culture medium $\left(90^{\circ} \mathrm{C}\right.$ and $\left.1000 \mathrm{rpm}\right)$ for $20 \mathrm{~min}$, sterilized, and then inoculated with $10 \mathrm{v} / \mathrm{v} \%$ of Komagataeibacter medellinensis, distributed in Petri dishes, and incubated for 15 days at $28^{\circ} \mathrm{C}$. These conditions were optimized in our previous efforts [26]. The obtained biomaterial was physically crosslinked in a Labconco FreeZone Bulk Tray Dryer at atmospheric pressure using six freezing/thawing cycles between $20^{\circ} \mathrm{C}$ and $-20^{\circ} \mathrm{C}$ using a heating/cooling rate of $0.1^{\circ} \mathrm{C} / \mathrm{min}$ and a holding time of $6 \mathrm{~h}$. The relative amount of $\mathrm{PVA} / \mathrm{BC}$ in the nanocomposite was ca. 80/20 wt \%. Purification of all biomaterials was performed as described for BC. After achieving $\mathrm{pH}=7.0$, and in order to sterilize the PVA and PVA/BC biomaterials for cell culture, they were oven-dried overnight at $50^{\circ} \mathrm{C}$, cut into discs to fit the wells in the polystyrene plate, and sterilized with ethylene oxide.

2.4. Composite Morphology. Scanning electron microscopy (SEM) was used to examine the microstructure of the biomaterials. The samples were swelled in distilled water to equilibrium and then dehydrated by lyophilisation; once dried, they were coated with gold ( $12 \mathrm{~nm}$ thick) using an ion sputter coater and observed with a Jeol JSM 5910 LV electron microscope operated at $10 \mathrm{kV}$ at 200,1000, and 5000x.

2.5. Wet Mechanical Strength. Young's modulus and tensile strength of the biomaterials (BC, PVA \& PVA/BC) in wet condition were evaluated in air using an Instron 5582 Universal Testing Machine, equipped with a $50 \mathrm{~N}$ load cell with a cross head speed of $12.5 \mathrm{~mm} / \mathrm{min}$. For testing, dumbbell shaped strips were used (dowel: width $5 \mathrm{~mm} \times$ length $18 \mathrm{~mm}$ ). The mechanical tensile data were collected for 7 different specimens per biomaterial type. Young's modulus and the tensile strength were determined according to ASTM D882 Standard Test Method for Tensile Properties of Thin Plastic Sheeting in the initial slope.

2.6. Swelling. The swelling ratio of biomaterial is relevant in characterizing the amount of nutrients available to cells and 
cell migration products [8]. The swelling measurements were carried out following the methodology reported by Chang et al. [40]. To reach swelling equilibrium, PVA and PVA/BC biomaterials were hydrated in distilled water for over 2 weeks at room temperature. The equilibrium-swelling ratio was experimentally determined as percentage of swelling $(S \%)$ using

$$
S \%=\frac{W_{s}}{W_{d}} * 100,
$$

where $W_{s}$ and $W_{d}$ are the weight of the swollen gel and dried material (drying at $70^{\circ} \mathrm{C}$ and 0.7 bar of vacuum) measured at room temperature. All measurements were recorded in triplicate. The kinetics of water uptake was determined with samples that were removed from water at regular time intervals. The weight of each sample was gravimetrically recorded. Before the measurements, the biomaterial surfaces were wiped with filter paper to remove superficial water. The sample weight was recorded as the average value of three measurements. The results are expressed as water uptake $\left(W_{u}\right)$ and calculated following

$$
W_{u}=\frac{\left(W_{t}-W_{d}\right)}{W_{s}} * 100,
$$

where $W_{t}$ is the weight of the swollen gel in distilled water at time $t$ at room temperature.

2.7. Cell Adhesion. Sterile BC, PVA, and PVA/BC biomaterials were placed in a six-well plate for cell culture and hydrated for 4 days with Dulbecco's Modified Eagle Medium (DMEM) and foetal calf serum (FCS) at $10 \mathrm{v} / \mathrm{v} \%$. After the fourth day, the medium was exchanged and 50,000 fibroblasts were seeded per well on the biomaterial surface. The incubation time was 8 days, with medium changes every fourth day. Fibroblasts, being present in great amounts on the skin, were chosen to conduct the test. They are responsible for skin cell regeneration and are used for testing biomaterials for skin substitutes [11, 33, 41, 42]. To monitor cell adhesion, the biomaterials were stained with haematoxylin-eosin and imaged with a Leica microscope and micrometrics camera. Furthermore, the BC-based biomaterial was stained with ethidium bromide, and fluorescence images were recorded using a Leica microscope at 40x and 100x and a Moticam (Motic) of 10 megapixels.

2.8. Cell Viability. The numbers of viable cells were quantified throughout the incubation time via the MTT (3-(4,5dimethylthiazol-2-yl)-2,5-diphenyl tetrazolium bromide) assay. This assay is based on the fact that only live cells can reduce 3-(4,5-dimethylthiazol-2-yl)-2,5-diphenyltetrazolium bromide (MTT) to formazan [43]. The protocol was performed as described by Weniger et al. [44]. Briefly, at 4 and 8 days' incubation time, the $\mathrm{BC}$ biomaterial was cut into small cubes, to fit the dimensions of a 96-well microtiter plate. To each well, $90 \mu \mathrm{L}$ of DMEM and $10 \mu \mathrm{L}$ of MTT $0.5 \mathrm{w} / \mathrm{v} \%$ were added. Next, the plate was incubated at $30^{\circ} \mathrm{C}$ and $70 \mathrm{rpm}$ for $3 \mathrm{~h}$. The insoluble formazan crystals formed were dissolved in $100 \mu \mathrm{L}$ of isopropanol for $20 \mathrm{~h}$ and measured spectrophotometrically in an enzyme-linked immunosorbent assay reader (MultiskanGO, Thermo Scientific) at $570 \mathrm{~nm}$ wavelength. The cell number per biomaterial was established by totalizing the number of cells per piece of biomaterial. Before the assay, a calibration curve was developed by using 8 successive dilutions to half the initial concentration, starting from 50,000 viable cells and following the procedure described above. The results were compared with Corning polystyrene well (control), which is the reference substrate for cell maintenance. The tests were carried out in triplicate at two independent times.

2.9. Histology. The histology procedure was performed to evaluate the cross adhesion of human fibroblasts within the BC-based biomaterial. Samples obtained after 16 days' cell culture were placed in a tissue processor (Thermo Scientific) for $12 \mathrm{~h}$ at room temperature. To dehydrate the samples, the following solvents were used: neutral formaldehyde, isopropanol between 50 and $80 \mathrm{v} / \mathrm{v} \%$, pure isopropanol, pure xylols, and paraffin at $60^{\circ} \mathrm{C}(1: 3: 3: 3: 2)$. After $12 \mathrm{~h}$, the biomaterials were embedded in a paraffin block at $56^{\circ} \mathrm{C}$ and were cut using a microtome (Leica) to produce $1 \mu \mathrm{m}$ thick cross sections. The sections were stained with haematoxylin-eosin and images were recorded using an Olympus microscope (100x).

2.10. 3D Moulding for Wound Dressing. Gloves were developed from BC. For this, an oxygen-permeable mould comprising silicon rubber was used. A nitrile glove was coated with catalyzed silicon rubber and left for $24 \mathrm{~h}$ to vulcanize the silicon; next, the silicon rubber glove was unmoulded. The silicon mould was sterilized, filled with $500 \mathrm{~mL}$ of HS culture medium, and inoculated at $10 \mathrm{v} / \mathrm{v} \%$ with Komagataeibacter medellinensis, and the system was incubated at room temperature for 10 days; then the gloved shaped BC dressing was unmoulded and purified as explained in previous sections for BC.

\section{Results and Discussion}

3.1. Biomaterial Morphology. The morphology of the biomaterials relates to their suitability for cell adhesion and biocompatibility. BC presents a fibrillar structure while pore features are typical in PVA and PVA/BC. The BC microstructure shows an open porous network (Figure $1 \mathrm{BC}$ at $5000 \mathrm{x}$ ), comprising interconnected nanoribbons, $50-70 \mathrm{~nm}$ in width, similar to collagen fibrils in the extracellular matrix (ECM) $[17,45]$. In the case of PVA/BC composites, the fibril structure of $\mathrm{BC}$ is covered by PVA (Figure 1), which results from the fact that cellulose acts as nucleation element for the PVA biopolymer. In this way, PVA crystals grow from the BC nanoribbons into the free spaces [46] (Figure 1, PVA/BC).

The morphology, including the texture and pore size, affects the adsorption and adhesion of proteins and, consequently, cell anchorage [47]. The dried PVA/BC nanocomposites presented large, closed pores, ca. $2 \mu \mathrm{m}$ in size, while PVA exhibited open pores ( $1 \mu \mathrm{m}$ in size, see Figure 1$)$. These 

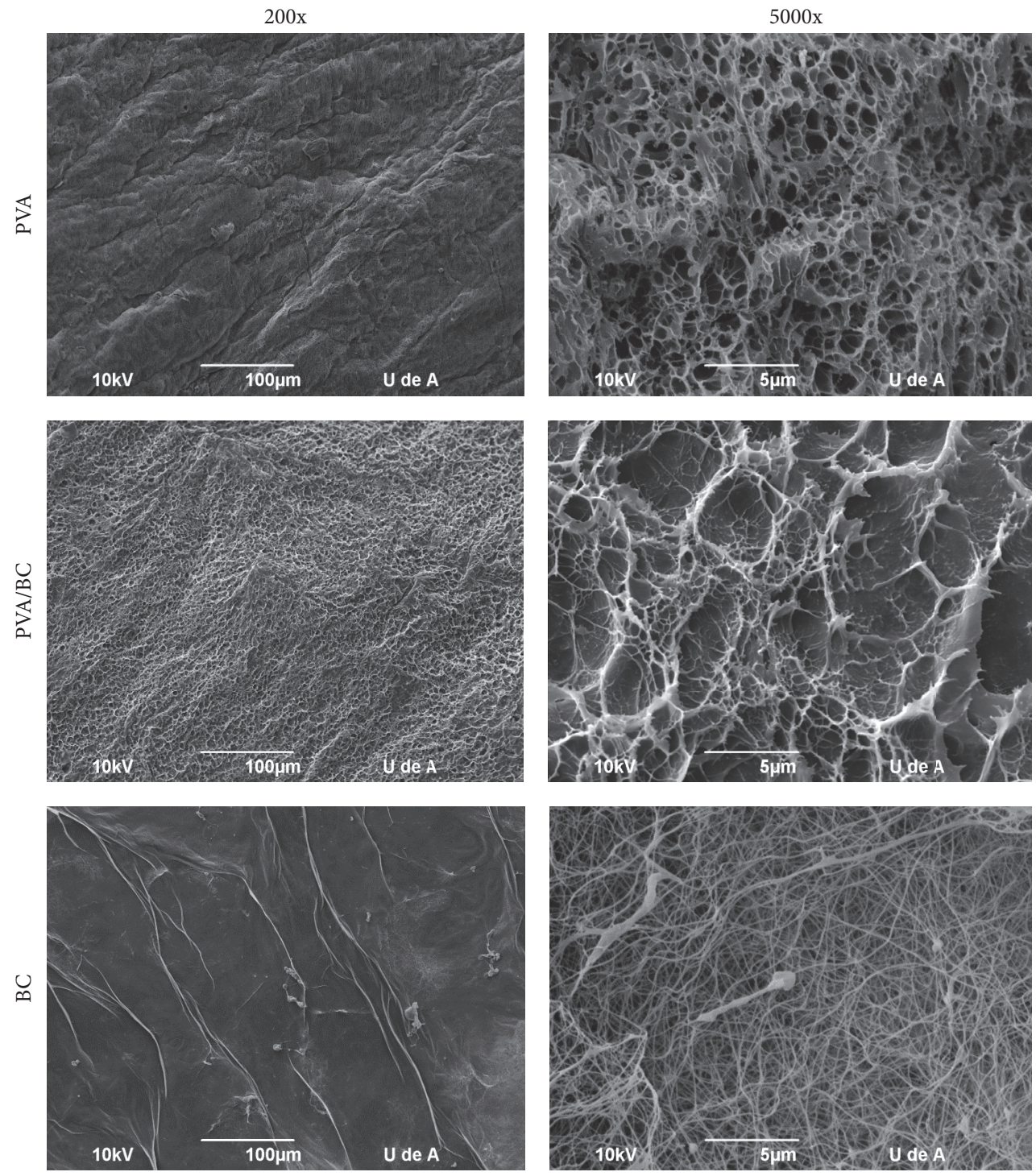

FIGURE 1: Microstructure of the dry biomaterials obtained from for PVA, PVA/BC nanocomposite, and BC as assessed by scanning electron micrographs at different magnifications (200 and 5000x).

results are related to phase separation during freeze-thawing [30]. Open porosity is desirable because it allows nutrient migration within the biomaterial and its supplementation to cells. Thus, compared to the PVA/BC nanocomposites, the single component $\mathrm{BC}$ and PVA are expected to exhibit higher cell adhesion.

3.2. Wet Mechanical Properties. The wet mechanical properties of BC, PVA, and PVA/BC biomaterials are presented as strain-stress profiles (Figure 2(a)). Hydrogels with viscoelastic behaviours were identified, similar to those of human tissue, skin, cartilage, and so on [23]. This was more distinctive for BC (Figure 2(b)), which showed a nonlinear response (toe-in region) as has been described elsewhere $[48,49]$. This region results from the gradual stretching of cellulose fibres upon loading, which is analogous to the function of collagen fibrils [48].
This response was not evident for PVA or PVA/BC, due to the highly entangled morphology that was generated during the physical crosslinking [25]. The incorporation of $\mathrm{BC}$ induced changes to the mechanical properties of PVA: the slope of the linear zone, related to the stiffness, increased due to the presence of the reinforcing BC. The skin elastic modulus is ca. $1-3 \mathrm{MPa}$ [50]. Compared to this value, the results in Table 1 indicate that the tested biomaterials have similar stiffness, which is expected to facilitate the comfort of patients, avoiding stress concentration between the dressing and the wounded area.

The values of tensile strength and Young modulus of the biomaterials are summarized in Table 1 . The inclusion of BC in PVA increased Young's modulus, which indicates a stiffening of the matrix. This behaviour resulted from good stress transfer upon the incorporation of the threedimensional BC nanoribbon network in PVA $[25,26,51]$. The 


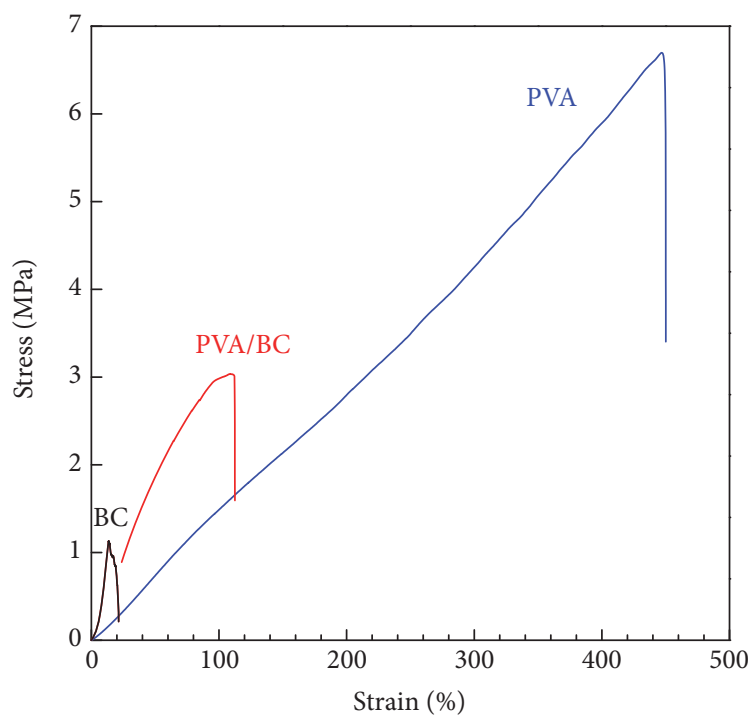

(a)

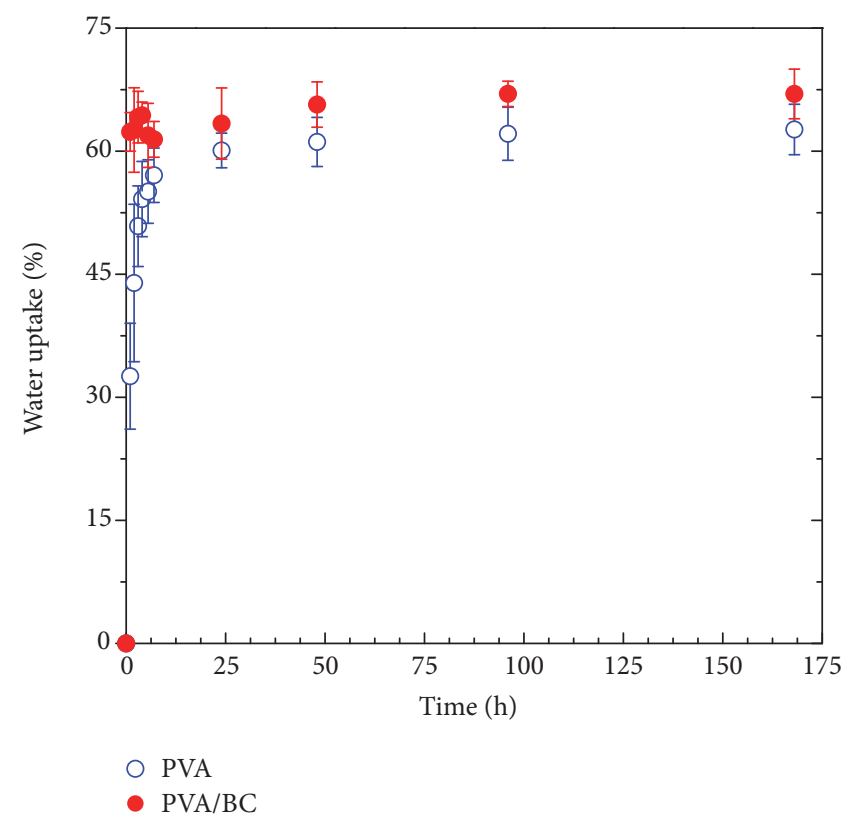

(b)

FIGURE 2: (a) Biomaterial strain-stress curves under uniaxial tension in the wet state for BC, PVA, and PVA/BC nanocomposites, as indicated. (b) Kinetics of water uptake for PVA and PVA/BC nanocomposite (biomaterial rehydration profiles). The water content was measured gravimetrically.

TABLE 1: Mechanical properties of biomaterials in the wet state: Young's modulus and tensile strength under uniaxial stress (the test was performed in air). Included is also the biomaterial swelling, swelling (\%), water content (wt.\%), time to reach equilibrium (h), and wet thickness (mm). Biomaterial swelling, swelling as percentage, was calculated according to (1). The time to reach swelling equilibrium was determined when mass changes of less than $1 \mathrm{wt} . \%$ were recorded. The wet thickness is reported in millimetres.

\begin{tabular}{|c|c|c|c|c|c|c|}
\hline Biomaterial & $\begin{array}{l}\text { Young's modulus } \\
\qquad(\mathrm{MPa})\end{array}$ & $\begin{array}{c}\text { Tensile strength } \\
\text { (MPa) }\end{array}$ & Swelling (\%) & $\begin{array}{l}\text { Water content } \\
\text { (wt.\%) }\end{array}$ & $\begin{array}{l}\text { Time to reach } \\
\text { equilibrium } \\
\text { (h) }\end{array}$ & $\begin{array}{l}\text { Wet thickness } \\
(\mathrm{mm})\end{array}$ \\
\hline$P V A$ & $1.13 \pm 0.25$ & $7.16 \pm 1.46$ & $298.93 \pm 4.91$ & $62.64 \pm 3.08$ & 5.5 & $0.42 \pm 0.28$ \\
\hline$P V A / B C$ & $2.29 \pm 0.46$ & $2.55 \pm 0.29$ & $305.65 \pm 7.06$ & $66.98 \pm 3.03$ & 1 & $0.17 \pm 0.04$ \\
\hline$B C$ & $3.30 \pm 0.97$ & $0.92 \pm 0.17$ & $6951.37 \pm 200.92$ & $98.56 \pm 0.04$ & N/A & $1.20 \pm 0.32$ \\
\hline
\end{tabular}

maximum tensile strength of the biomaterial is influenced by the presence of water, which interferes in the interaction of polymer chains [52]. The tensile strength of PVA was reduced by the incorporation of BC. This is explained by the fact that, in the wet state, $\mathrm{BC}$ acts as a stress concentrator, because of the interference of water located between the matrix and the reinforcement, at the interfaces in the composite [52].

A Young's modulus of ca. $3 \mathrm{MPa}$ was measured for the BC hydrogels, in agreement with other reports [53, 54]. The nanoribbons are linked to bulk water [8]; moreover according to Konidari et al., water induces changes in the mechanical properties of semicrystalline polymers due to the plasticization of the amorphous regions and the possible partial destruction of the crystalline ones [55]. Despite the loss of mechanical performance (tensile strength) in the presence of water, the hydrogel morphology is desirable for cell regeneration since it mimics the morphology of collagen [11] and, according to Bäckdahl et al. and Fu et al., this type of effect is beneficial for the formation of cell layers on the biomaterial $[53,54]$.
3.3. Swelling. Figure 2(b) illustrates the swelling behaviour of PVA and PVA/BC nanocomposite, including their swelling percentage, water content, time to reach swelling equilibrium, and wet thickness. PVA and PVA/BC presented ca. 300\% swelling, indicating that the reinforcement of PVA with BC did not affect its ability to absorb water. BC has a large capacity to hold water $(99 \pm 0.04 \mathrm{wt} . \%)$, equivalent to a relative swelling of ca. $7000 \%$. The water holding capacity in biomaterials is important because it determines the amount of nutrients available to the cells [8]. Accordingly, these results indicate the possibility of an extensive cell adhesion.

Regarding the kinetics of water uptake, swelling equilibrium for PVA and PVA/BC biomaterials is not affected by the inclusion of BC (ca. $67 \mathrm{wt} \%$ water content) (Table 1). PVA/BC reached equilibrium in $1 \mathrm{~h}$, while PVA took $5.5 \mathrm{~h}$. However, compared with PVA, the rate of water uptake is higher for the PVA/BC nanocomposites. This behaviour is related to the thickness of the biomaterial (Table 1), which affects the diffusion of water, as described by Fick's second law [56]. The thickness of the nanocomposite is difficult 


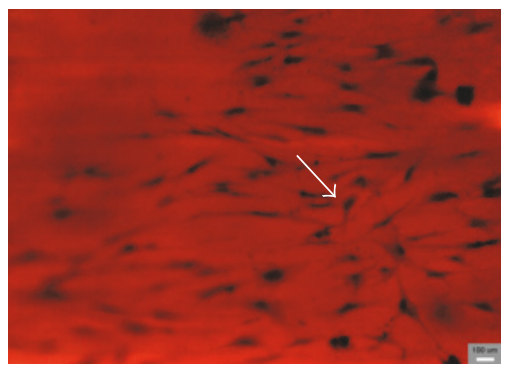

(a)

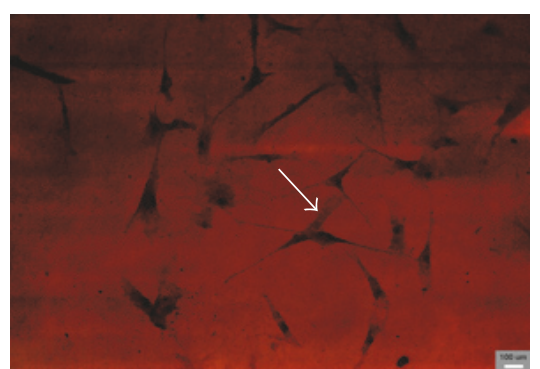

(b)

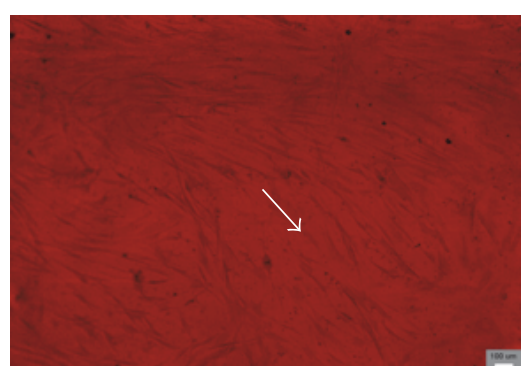

(c)

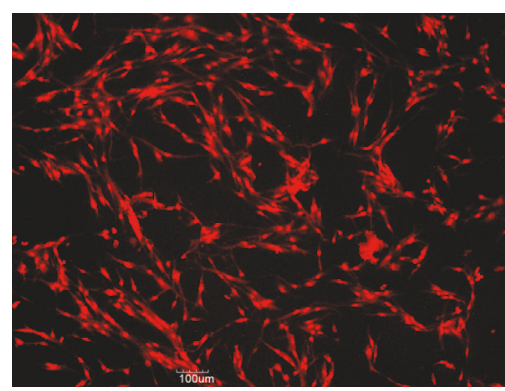

(d)

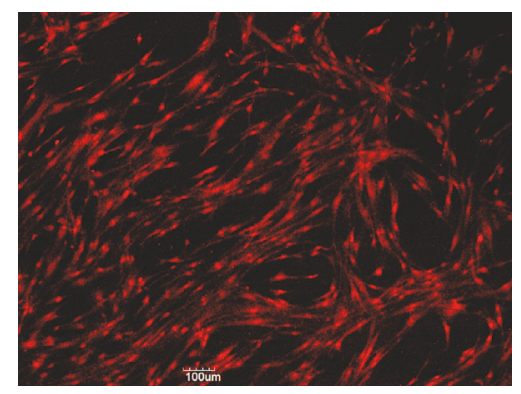

(e)

FIGURE 3: In vitro cell adhesion on biomaterials, haematoxylin-eosin staining incubation time of 8 days. (a) PVA, (b) PVA/BC, and (c) BC. Images taken at 40x. White arrows indicate the presence of cells. Cell densities: PVA and PVA/BC not detectable; BC $56934 \pm 4657$. Fluorescent images of fibroblast on BC, (d) 4th day and (e) 8th day. Dye: ethidium bromide, cell nucleus is brighter than cytoplasm. Images token at 40x. Fibroblasts increase their number on BC. At the 4th day cells are spread on the surface of BC surface. At the 8th day, cells display a confluent monolayer on the surface of the biomaterial. Scale bar is $100 \mu \mathrm{m}$.

to control in the in situ methodology because it depends on the number of viable bacteria at the air-liquid interface. We note that BC swelling occurs during fermentation, and rehydration is limited after the material has been dried, due to the "hornification" phenomenon [57].

3.4. In Vitro Cell Adhesion. The results for cell adhesion on the biomaterials are shown in Figure 3. Adhesion was observed for PVA, PVA/BC, and BC. For the PVA/BC nanocomposite the closed pores affected the adhesion of fibroblasts on the biomaterial. This is likely because adsorption and adhesion of proteins are hindered by the reduced availability of nutrients [47]. Moreover, cells anchored scarcely on PVA and PVA/BC, as observed in Figure 3. In both cases, the number of cells was low compared to BC; from 50000 cells seeded only a few were detected. MTT assay did not reveal any significant changes.

According to fluorescence imaging (see Figures 3(d) and 3(e)) and MTT assessment of human fibroblasts on $\mathrm{BC}$ (Table 2), cells adhered to the $\mathrm{BC}$ biomaterial in great numbers. Cells anchored to BC from the fourth day. At the 8th day, a confluent fibroblast monolayer was evident wherein the cells displayed a fusiform morphology. This type of morphology indicates healthy cells and appropriate anchorage on $\mathrm{BC}[58,59]$. This is explained by the $\mathrm{BC}$ microstructure, similar to that of collagen, and its chemical configuration with three hydroxyl groups per monomer that interact with polar sites in the cell through hydrogen bonds [60]. Likewise, the high swelling of BC and its open porosity
TABle 2: Cell density on BC with time. Plates for cell culture of polystyrene were used as control.

\begin{tabular}{lcc}
\hline Biomaterial & \multicolumn{2}{c}{ Time $(\mathrm{d})$} \\
\hline BC & $15349 \pm 10227$ & 8 \\
Control & $35265 \pm 11064$ & $56934 \pm 4657$ \\
\hline
\end{tabular}

facilitated the sorption of cell culture medium; these factors promoted cell anchorage.

Despite the presence of abundant hydroxyl groups in PVA, protein adsorption and cell adhesion were prevented [61]. In BC, fibroblasts adhered, a phenomenon that did not occur in PVA/BC (see Figure 3). Thus, PVA/BC can be better used as interactive dressings where cell adhesion is not required, or even is unwanted [14]. Nonetheless according to the swelling results these biomaterials control moisture, that is, control exudate, without interacting directly with the wound bed (cells). Others possible biomedical applications of the PVA/BC nanocomposite include the development of dura mater implants, drug delivery systems, and protein immobilization [62-64]. In these applications cell adhesion is not required.

3.5. Cell Viability. Cell viability is a critical test for wound dressings, since they interact with cells and promote cell movement to the injury site [65]. Table 2 shows the results of the MTT viability test. 


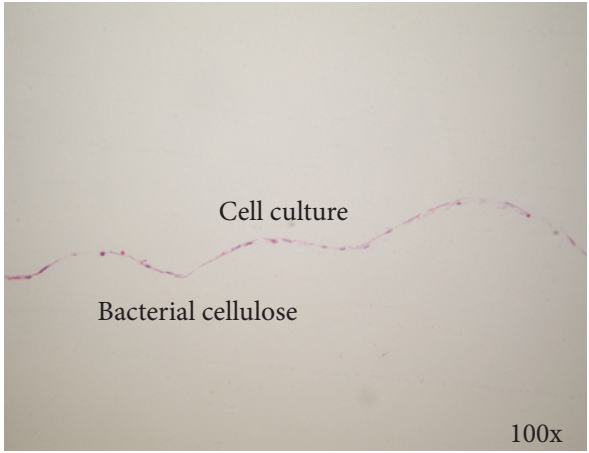

(a)

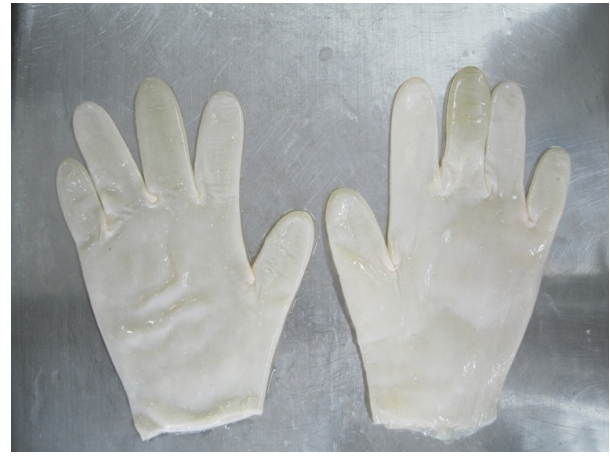

(b)

FIGURE 4: BC wound dressing: (a) side view of BC histology cut, cells adhere on the biomaterial surface (image taken at 100x). (b) BC gloveshaped wound dressing (hydrogel state) for treatment of hand lesions, especially those involving fingers.

The number of viable cells on $\mathrm{BC}$ at day 8 was similar to that on the control. However, cells on $\mathrm{BC}$ increase in their number faster than in the control; from day 4 to 8 , cells on BC increased fourfold in number. This effect can be attributed to the $\mathrm{BC}$ microstructure and its surface chemistry [60], as explained previously. The fact that fibroblasts are viable on $\mathrm{BC}$ means that this biomaterial does not interfere in the cell cycle, which make BC suitable for skin cell regeneration as a bioactive wound dressing [6]. This result is in agreement with fluorescent imaging (see Figures 3(d) and 3(e)): good adhesion was observed on BC from day 4; at day 8 , a fibroblast monolayer was observed as a fusiform and confluent morphology [32].

3.6. Histology. Figure 4(a) shows the side view of a monolayer of fibroblasts on BC. It indicates that they did not migrate across the biomaterial, as the pore size of the $\mathrm{BC}$ is c.a. $1 \mu \mathrm{m}$ in size and cells have an average size of $40 \mu \mathrm{m}$ [66]. However, it has been indicated in the literature that cells can push $\mathrm{BC}$ nanoribbons and migrate transversely $[67,68]$. This phenomenon seemed not to occur in this case because of the highly entangled BC network, which excluded cells by size.

Currently, research focuses on creating microporosities in $\mathrm{BC}$ in order to enhance cell migration; some remarkable strategies include the creation of sponges, inclusion of paraffin spheres, and development of cocoon-like structures $[12,66,69,70]$. For wound dressing the fact that cells do not migrate transversally in BC may be beneficial, for example, in creating monolayers of bioengineered skin substitutes. According to the results above, $\mathrm{BC}$ wound dressings can be classified as bioactive; $\mathrm{BC}$ is able to control moisture while interacting with skin cells. One interesting application is the development of tissue engineering skin substitutes, where $\mathrm{BC}$ can be covered by skin cells and then used for wound treatments [6]. The addition of PVA will generate an interactive wound dressing for the exudates management, where interactions with cells are not required.

3.7. Glove-Shaped Wound Dressing. According to the results presented for BC, a glove-shaped wound dressing was designed for treating burns and skin ulcers (Figure 4(b)). For these treatments, the high water holding capacity of $\mathrm{BC}$ and its biocompatibility with skin cells are important to keep the wound moist and to promote fibroblast adhesion, respectively. All the above promote epithelialization and wound healing [1].

The benefits of wound dressings can be expanded if they are made from BC. Furthermore, the production of related wound dressings is possible by using microorganism bioengineering, using a silicone rubber membrane template (permeable to oxygen). Only bacteria (Komagataeibacter medellinensis) next to the inner mould wall have access to oxygen and divide and produce cellulose. Therefore, BC is produced only adjacent to the silicone rubber and it will conform to the shape of the mould, a glove in this case. Such wound dressings can be used as skin substitutes for difficult areas such as hands and fingers.

\section{Conclusions}

A facile, robust, and novel method toward nanocomposites with biocompatible bacterial cellulose (BC) and polyvinyl alcohol (PVA) was applied by in situ fermentation and physical crosslinking upon cellulose biosynthesized from Komagataeibacter medellinensis. BC-based hydrogels were found to be beneficial for the formation of a cell layer on the biomaterial. $\mathrm{BC}$ presented a high degree of swelling, which is vital for nutrient and adhesion protein adsorption. The microstructure of PVA and PVA/BC scarcely allowed cell adhesion. In contrast, fibroblasts cultured on BC were identified in large number, forming fusiform and confluent morphology. This observation is explained by the similarity of $\mathrm{BC}$ with collagen. According to viability tests, fibroblasts multiplied rapidly on $\mathrm{BC}$, and the fibroblast monolayer did not migrate significantly across the biomaterial. This is mainly due to size exclusion effects; this is advantageous for bioengineering monolayers of skin substitutes. According to the properties presented by $\mathrm{BC}$ and taking advantage of microorganism bioengineering, it was possible to develop $\mathrm{BC}$ shaped as a glove for wound dressing. This material may have application in the treatment of skin burns and ulcers. In 
conclusion, PVA and PVA/BC nanocomposites can be used if cell adhesion is not required, for instance, as interactive wound dressing for exudate management. BC is ideally suited as a bioactive wound dressing for development of bioengineered skin substitutes; thus the biomaterials can be used as wound dressings depending on the clinical situation. Further investigation will be focused on in vivo studies to validate the systems under real conditions, to determine their safety in use and their pharmacokinetics.

\section{Conflicts of Interest}

The authors declare that there are no conflicts of interest regarding the publication of this paper nor financial interest in the subject matter or materials discussed in this manuscript.

\section{Acknowledgments}

The authors acknowledge the Universidad Pontificia Bolivariana, CIDI-UPB, Colombia, and Colciencias, Colombia, for the funding support that allowed the completion of this research.

\section{References}

[1] W. Czaja, "Biomedical applications of microbial cellulose in burn wound recovery," in Cellulose: Molecular and Structural Biology, R. M. J. Brown and I. M. Saxena, Eds., pp. 307-321, Springer, Dordrecht, Netherlands, 2007.

[2] T. T. Nguyen, D. A. Gilpin, N. A. Meyer, and D. N. Herndon, "Current treatment of severely burned patients," Annals of Surgery, vol. 223, no. 1, pp. 14-25, 1996.

[3] B. S. Atiyeh, S. W. Gunn, and S. N. Hayek, "State of the art in burn treatment," World Journal of Surgery, vol. 29, no. 2, pp. 131148, 2005.

[4] E. D. Morgan, E. Army, and F. Gordon, "Ambulatory management of burns," American Family Physician ${ }^{\circledR}$, vol. 62, no. 9, pp. 1-16, 2013.

[5] N. E. E. van Loey and M. J. M. van Son, "Psychopathology and psychological problems in patients with burn scars: epidemiology and management," The American Journal of Clinical Dermatology, vol. 4, no. 4, pp. 245-272, 2003.

[6] S. Dhivya, V. V. Padma, and E. Santhini, "Wound dressings-a review," Biomedicine (Taipei), vol. 5, no. 4, p. 22, 2015.

[7] Y. Liu, N. E. Vrana, P. A. Cahill, and G. B. McGuinness, "Physically crosslinked composite hydrogels of PVA with natural macromolecules: Structure, mechanical properties, and endothelial cell compatibility," Journal of Biomedical Materials Research - Part B Applied Biomaterials, vol. 90, no. 2, pp. 492502, 2009.

[8] A. S. Hoffman, "Hydrogels for biomedical applications," Advanced Drug Delivery Reviews, vol. 64, pp. 18-23, 2012.

[9] M. Gamma, P. Gatenholm, and D. Klemm, Bacterial Nanocellulose a Sophisticated Multifunctional Material, CRC Press Taylor \& Francis Group, Boca Raton, Florida, USA, 1st edition, 2013.

[10] D. A. Schumann, J. Wippermann, D. O. Klemm et al., "Artificial vascular implants from bacterial cellulose: preliminary results of small arterial substitutes," Cellulose, vol. 16, no. 5, pp. 877$885,2009$.
[11] L. Fu, J. Zhang, and G. Yang, "Present status and applications of bacterial cellulose-based materials for skin tissue repair," Carbohydrate Polymers, vol. 92, no. 2, pp. 1432-1442, 2013.

[12] H. Bäckdahl, M. Esguerra, D. Delbro, B. Risberg, and P. Gatenholm, "Engineering microporosity in bacterial cellulose scaffolds," Journal of Tissue Engineering and Regenerative Medicine, vol. 2, no. 6, pp. 320-330, 2008.

[13] D. Queen, H. Orsted, H. Sanada, and G. Sussman, "A dressing history," International Wound Journal, vol. 1, no. 1, pp. 59-77, 2004.

[14] S. Sarabahi, "Recent advances in topical wound care," Indian Journal of Plastic Surgery, vol. 45, no. 2, pp. 379-387, 2012.

[15] M. H. Damanhuri and J. M. Boyle, "Advances in tissueengineered skin substitutes," Wounds International, vol. 2, no. 1, pp. 27-34, 2011.

[16] B. Gupta, R. Agarwal, and M. S. Alam, "Textile-based smart wound dressings," Indian Journal of Fibre and Textile Research, vol. 35, no. 2, pp. 174-187, 2010.

[17] F. Torres, S. Commeaux, and O. Troncoso, "Biocompatibility of bacterial cellulose based biomaterials," Journal of Functional Biomaterials, vol. 3, no. 4, pp. 864-878, 2012.

[18] G. Helenius, H. Bäckdahl, A. Bodin, U. Nannmark, P. Gatenholm, and B. Risberg, "In vivo biocompatibility of bacterial cellulose," Journal of Biomedical Materials Research Part A, vol. 76, no. 2, pp. 431-438, 2006.

[19] B. D. Ratner, "The biocompatibility manifesto: biocompatibility for the twenty-first century," Journal of Cardiovascular Translational Research, vol. 4, no. 5, pp. 523-527, 2011.

[20] J. Wang, C. Gao, Y. Zhang, and Y. Wan, "Preparation and in vitro characterization of BC/PVA hydrogel composite for its potential use as artificial cornea biomaterial," Materials Science and Engineering C, vol. 30, no. 1, pp. 214-218, 2010.

[21] M. I. Baker, S. P. Walsh, Z. Schwartz, and B. D. Boyan, "A review of polyvinyl alcohol and its uses in cartilage and orthopedic applications," Journal of Biomedical Materials Research B: Applied Biomaterials, vol. 100, no. 5, pp. 1451-1457, 2012.

[22] H. Mohammadi, "Nanocomposite biomaterial mimicking aortic heart valve leaflet mechanical behaviour," Proceedings of the Institution of Mechanical Engineers, Part H: Journal of Engineering in Medicine, vol. 225, no. 7, pp. 718-722, 2011.

[23] L. E. Millon and W. K. Wan, "The polyvinyl alcohol-bacterial cellulose system as a new nanocomposite for biomedical applications," Journal of Biomedical Materials Research - Part B Applied Biomaterials, vol. 79, no. 2, pp. 245-253, 2006.

[24] S. Gea, E. Bilotti, C. T. Reynolds, N. Soykeabkeaw, and T. Peijs, "Bacterial cellulose-poly(vinyl alcohol) nanocomposites prepared by an in-situ process," Materials Letters, vol. 64, no. 8, pp. 901-904, 2010.

[25] C. Castro, A. Vesterinen, R. Zuluaga et al., "In situ production of nanocomposites of poly(vinyl alcohol) and cellulose nanofibrils from Gluconacetobacter bacteria: Effect of chemical crosslinking," Cellulose, vol. 21, no. 3, pp. 1745-1756, 2014.

[26] C. Castro, R. Zuluaga, O. J. Rojas et al., "Highly percolated poly(vinyl alcohol) and bacterial nanocellulose synthesized in situ by physical-crosslinking: exploiting polymer synergies for biomedical nanocomposites," RSC Advances, vol. 5, no. 110, pp. 90742-90749, 2015.

[27] J. Rojas and E. Azevedo, "Surface functionalization of nanofibrillated cellulose using click-chemistry approach in aqueous media," International Journal of Pharmaceutical Sciences Review and Research, vol. 8, no. 1, pp. 1201-1212, 2011. 
[28] L. E. Millon, H. Mohammadi, and W. K. Wan, "Anisotropic polyvinyl alcohol hydrogel for cardiovascular applications," Journal of Biomedical Materials Research - Part B Applied Biomaterials, vol. 79, no. 2, pp. 305-311, 2006.

[29] L. E. Millon, G. Guhados, and W. Wan, "Anisotropic polyvinyl alcohol-bacterial cellulose nanocomposite for biomedical applications," Journal of Biomedical Materials Research Part B: Applied Biomaterials, vol. 86, no. 2, pp. 444-452, 2008.

[30] L. E. Millon, C. J. Oates, and W. Wan, "Compression properties of polyvinyl alcohol-bacterial cellulose nanocomposite," Journal of Biomedical Materials Research - Part B Applied Biomaterials, vol. 90, no. 2, pp. 922-929, 2009.

[31] J. A. Stammen, S. Williams, D. N. Ku, and R. E. Guldberg, "Mechanical properties of a novel PVA hydrogel in shear and unconfined compression," Biomaterials, vol. 22, no. 8, pp. 799$806,2001$.

[32] N. Sanchavanakit, W. Sangrungraungroj, R. Kaomongkolgit, T. Banaprasert, P. Pavasant, and M. Phisalaphong, "Growth of human keratinocytes and fibroblasts on bacterial cellulose film," Biotechnology Progress, vol. 22, no. 4, pp. 1194-1199, 2006.

[33] F. Lina, Z. Yue, Z. Jin, and Y. Guang, "Bacterial cellulose for skin repair materials," in Biomedical Engineering-Frontiers and Challenges, pp. 249-274, 2009.

[34] R. A. N. Pértile, S. Moreira, R. M. Gil Da Costa et al., "Bacterial cellulose: Long-term biocompatibility studies," Journal of Biomaterials Science, Polymer Edition, vol. 23, no. 10, pp. 1339-1354, 2012.

[35] J. M. Dugan, J. E. Gough, and S. J. Eichhorn, "Bacterial cellulose scaffolds and cellulose nanowhiskers for tissue engineering," Nanomedicine, vol. 8, no. 2, pp. 287-298, 2013.

[36] Y. Yamada, "Transfer of Gluconacetobacter kakiaceti, Gluconacetobacter medellinensis and Gluconacetobacter maltaceti to the genus komagataeibacter as komagataeibacter kakiaceti comb. nov., komagataeibacter medellinensis comb. nov. and komagataeibacter maltaceti comb. nov," International Journal of Systematic and Evolutionary Microbiology, vol. 64, no. 5, pp. 1670-1672, 2014.

[37] C. Castro, I. Cleenwerck, J. Trček et al., "Gluconacetobacter medellinensis sp. nov., cellulose- and non-cellulose-producing acetic acid bacteria isolated from vinegar," International Journal of Systematic and Evolutionary Microbiology, vol. 63, no. 3, pp. 1119-1125, 2013.

[38] C. Castro, R. Zuluaga, C. Álvarez et al., "Bacterial cellulose produced by a new acid-resistant strain of Gluconacetobacter genus," Carbohydrate Polymers, vol. 89, no. 4, pp. 1033-1037, 2012.

[39] M. Schramm and S. Hestrin, "Factors affecting production of cellulose at the air/liquid interface of a culture of Acetobacter xylinum," Journal of General Microbiology, vol. 11, no. 1, pp. 123129, 1954.

[40] C. Chang, A. Lue, and L. Zhang, "Effects of crosslinking methods on structure and properties of cellulose/PVA hydrogels," Macromolecular Chemistry and Physics, vol. 209, no. 12, pp. 1266-1273, 2008.

[41] L. L. Hench and I. Thompson, "Twenty-first century challenges for biomaterials," Journal of the Royal Society Interface, vol. 7, no. 4, pp. S379-S391, 2010.

[42] E. Middelkoop, A. J. Van Den Bogaerdt, E. N. Lamme, M. J. Hoekstra, K. Brandsma, and M. M. W. Ulrich, "Porcine wound models for skin substitution and burn treatment," Biomaterials, vol. 25, no. 9, pp. 1559-1567, 2004.
[43] T. Mosmann, "Rapid colorimetric assay for cellular growth and survival: application to proliferation and cytotoxicity assays," Journal of Immunological Methods, vol. 65, no. 1-2, pp. 55-63, 1983.

[44] B. Weniger, S. Robledo, G. J. Arango et al., "Antiprotozoal activities of Colombian plants," Journal of Ethnopharmacology, vol. 78, no. 2-3, pp. 193-200, 2001.

[45] J. J. Norman and T. A. Desai, "Methods for fabrication of nanoscale topography for tissue engineering scaffolds," Annals of Biomedical Engineering, vol. 34, no. 1, pp. 89-101, 2006.

[46] R. Yudianti and M. Karina, "Development of Nanocomposites from Bacterial Cellulose and Poly(vinyl Alcohol) using Castingdrying Method," Procedia Chemistry, vol. 4, no. 2, pp. 73-79, 2012.

[47] G. Zhao, Z. Schwartz, M. Wieland et al., "High surface energy enhances cell response to titanium substrate microstructure," Journal of Biomedical Materials Research. Part A, vol. 74, no. 1, pp. 49-58, 2005.

[48] H. Zahedmanesh, J. N. Mackle, A. Sellborn et al., "Bacterial cellulose as a potential vascular graft: Mechanical characterization and constitutive model development," Journal of Biomedical Materials Research Part B: Applied Biomaterials, vol. 97, no. 1, pp. 105-113, 2011.

[49] M. Zaborowska, A. Bodin, H. Bäckdahl, J. Popp, A. Goldstein, and P. Gatenholm, "Microporous bacterial cellulose as a potential scaffold for bone regeneration," Acta Biomaterialia, vol. 6, no. 7, pp. 2540-2547, 2010.

[50] A. Ní Annaidh, K. Bruyère, M. Destrade, M. D. Gilchrist, and M. Otténio, "Characterization of the anisotropic mechanical properties of excised human skin," Journal of the Mechanical Behavior of Biomedical Materials, vol. 5, no. 1, pp. 139-148, 2012.

[51] C. Tang and H. Liu, "Cellulose nanofiber reinforced poly(vinyl alcohol) composite film with high visible light transmittance," Composites Part A: Applied Science and Manufacturing, vol. 39, no. 10, pp. 1638-1643, 2008.

[52] S. G. Lee, G. F. Brunello, S. S. Jang, and D. G. Bucknall, "Molecular dynamics simulation study of P (VP-co-HEMA) hydrogels: Effect of water content on equilibrium structures and mechanical properties," Biomaterials, vol. 30, no. 30, pp. 6130 6141, 2009.

[53] H. Bäckdahl, G. Helenius, A. Bodin et al., "Mechanical properties of bacterial cellulose and interactions with smooth muscle cells," Biomaterials, vol. 27, no. 9, pp. 2141-2149, 2006.

[54] L. Fu, P. Zhou, S. Zhang, and G. Yang, "Evaluation of bacterial nanocellulose-based uniform wound dressing for large area skin transplantation," Materials Science and Engineering C, vol. 33, no. 5, pp. 2995-3000, 2013.

[55] M. V. Konidari, K. G. Papadokostaki, and M. Sanopoulou, "Moisture-induced effects on the tensile mechanical properties and glass-transition temperature of poly(vinyl alcohol) films," Journal of Applied Polymer Science, vol. 120, no. 6, pp. 3381-3386, 2011.

[56] R. B. Bird, W. E. Stewart, and E. N. Lightfoot, Fenomenos de Transporte, Reverte, Barcelona, Spain, 1986.

[57] J. M. B. Fernandes Diniz, M. H. Gil, and J. A. A. M. Castro, "Hornification - Its origin and interpretation in wood pulps," Wood Science and Technology, vol. 37, no. 6, pp. 489-494, 2004.

[58] D. Bishop-Bailey and T. Hla, "Endothelial cell apoptosis induced by the peroxisome proliferator-activated receptor (PPAR) ligand 15-deoxy- $\Delta^{12,14}$-prostaglandin $\mathrm{J}_{2}$," Journal of Biological Chemistry, vol. 274, no. 24, pp. 17042-17048, 1999. 
[59] J. Yuan and G. Kroemer, "Alternative cell death mechanisms in development and beyond," Genes and Development, vol. 24, no. 23, pp. 2592-2602, 2010.

[60] J. H. Lee, H. W. Jung, I.-K. Kang, and H. B. Lee, "Cell behaviour on polymer surfaces with different functional groups," Biomaterials, vol. 15, no. 9, pp. 705-711, 1994.

[61] A. D. Doyle, F. W. Wang, K. Matsumoto, and K. M. Yamada, "One-dimensional topography underlies three-dimensional fi brillar cell migration," Journal of Cell Biology, vol. 184, no. 4, pp. 481-490, 2009.

[62] Y. Zhang, P. C. Zhu, and D. Edgren, "Crosslinking reaction of poly(vinyl alcohol) with glyoxal," Journal of Polymer Research, vol. 17, no. 5, pp. 725-730, 2010.

[63] C. Xu, X. Ma, S. Chen, M. Tao, L. Yuan, and Y. Jing, "Bacterial cellulose membranes used as artificial substitutes for dural defection in rabbits," International Journal of Molecular Sciences, vol. 15, no. 6, pp. 10855-10867, 2014.

[64] Y. Wang and Y.-L. Hsieh, "Immobilization of lipase enzyme in polyvinyl alcohol (PVA) nanofibrous membranes," Journal of Membrane Science, vol. 309, no. 1-2, pp. 73-81, 2008.

[65] M. Gama, P. Gatenholm, D. Klemm, and E. Al, Bacterial nanoCellulose a sophisticates multifunctional material, CRC Press Taylor \& Francis Group, Boca Raton, Florida, USA, 2013.

[66] D. O. S. Recouvreux, C. R. Rambo, F. V. Berti, C. A. Carminatti, R. V. Antônio, and L. M. Porto, "Novel three-dimensional cocoon-like hydrogels for soft tissue regeneration," Materials Science and Engineering C, vol. 31, no. 2, pp. 151-157, 2011.

[67] W. K. Czaja, D. J. Young, M. Kawecki, and R. M. Brown Jr., "The future prospects of microbial cellulose in biomedical applications," Biomacromolecules, vol. 8, no. 1, pp. 1-12, 2007.

[68] F. K. Andrade, R. Costa, L. Domingues, R. Soares, and M. Gama, "Improving bacterial cellulose for blood vessel replacement: Functionalization with a chimeric protein containing a cellulose-binding module and an adhesion peptide," Acta Biomaterialia, vol. 6, no. 10, pp. 4034-4041, 2010.

[69] C. Gao, Y. Wan, C. Yang et al., "Preparation and characterization of bacterial cellulose sponge with hierarchical pore structure as tissue engineering scaffold," Journal of Porous Materials, vol. 18, no. 2, pp. 139-145, 2011.

[70] R. M. Domingues, M. E. Gomes, and R. L. Reis, "The potential of cellulose nanocrystals in tissue engineering strategies," Biomacromolecules, vol. 15, no. 7, pp. 2327-2346, 2014. 

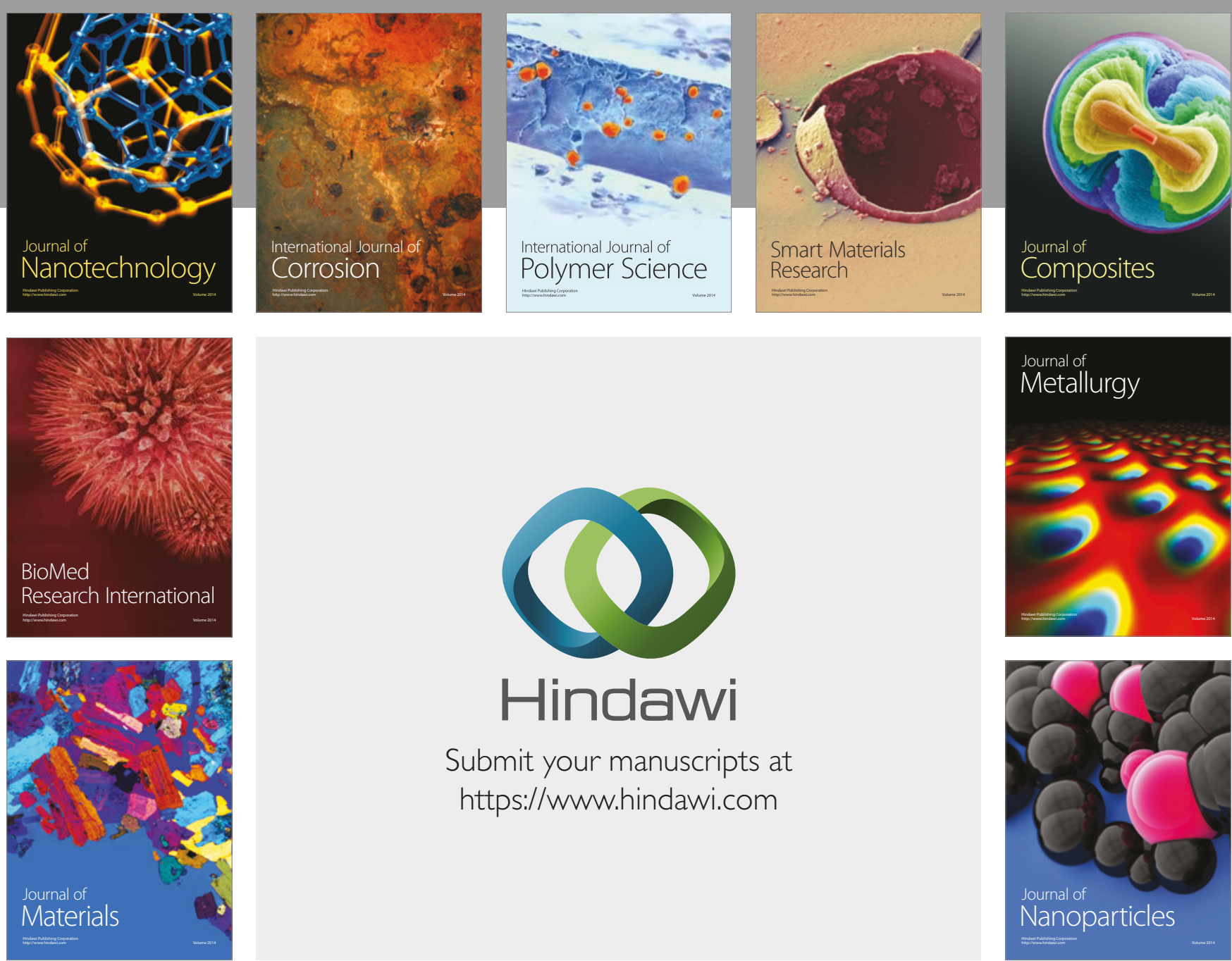

\section{Hindawi}

Submit your manuscripts at

https://www.hindawi.com
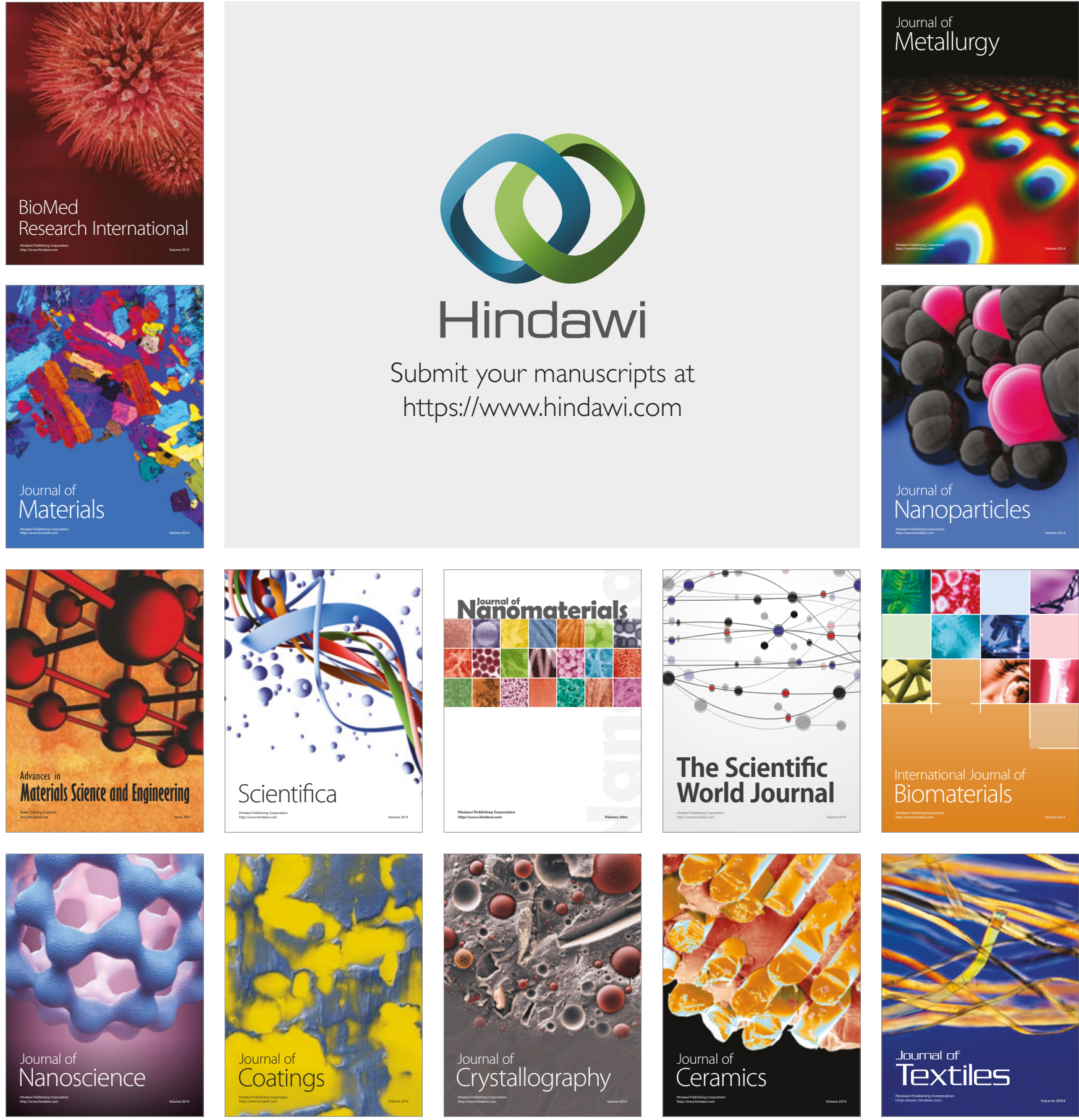

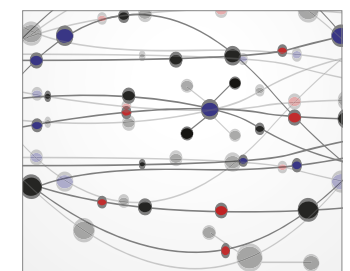

The Scientific World Journal
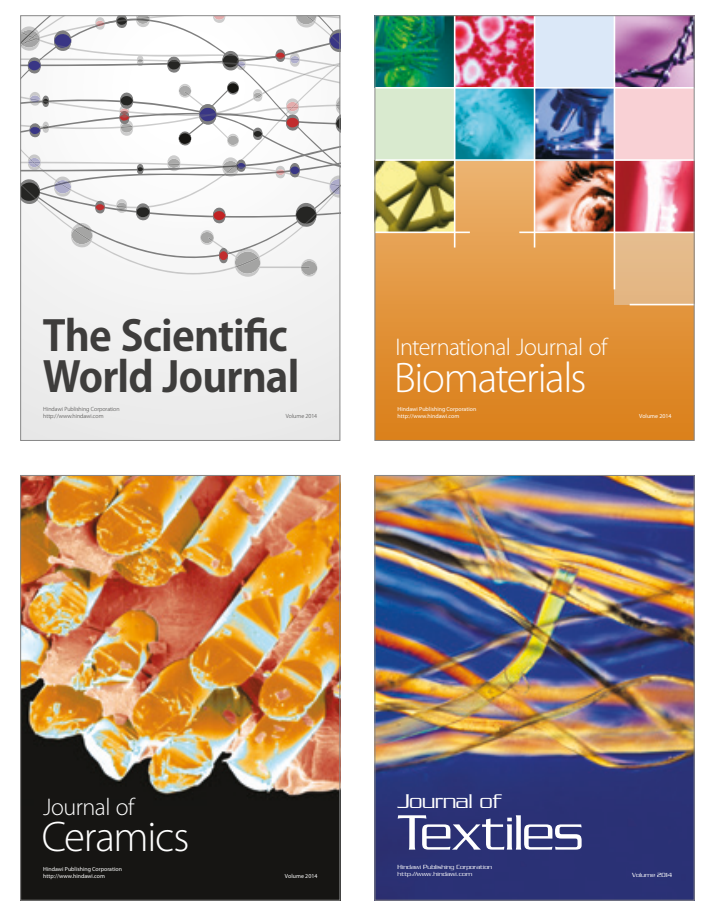